Z inicjatywy studentów i doktorantów Instytutu Informacji Naukowej i Bibliologii [dalej: IINiB UMK] w wyniku przekształcenia Koła Naukowego Specjalistów Informacji Uniwersytetu Mikołaja Kopernika [dalej: KNSI], w październiku 2014 r. powstało Studencko-Doktoranckie Koło Naukowe „ePRINT” [dalej: SDKN ePRINT]. Organizacja stanowi połączenie zarówno obszarów badawczych, jak i członków trzech kół naukowych działających dotychczas przy Instytucie Informacji Naukowej i Bibliologii: Koła Naukowego Specjalistów Informacji, Prasoznawczego Koła Naukowego oraz Doktoranckiego Koła Naukowego „Książka. Informacja. Media". Członkowie pragną w ten sposób połączyć potencjał i specyfikę działalności trzech organizacji studenckich w celu pełniejszego i efektywniejszego działania na polu naukowym i pozanaukowym.

Nazwa „ePRINT” nakreśla w sposób ogólny obszary zainteresowań naukowych i działalności Koła: PR-asa, IN-formacja, T-erapia (biblioterapia). Przedrostek „e" dodatkowo wskazuje na szczególny nacisk położony na aspekt pośrednictwa elektronicznych mediów, zwłaszcza Internetu.

Na czele SDKN ePRINT stanął nowy Zarząd Koła w składzie: przewodniczący Koła - mgr Marcin Karwowski, v-ce przewodnicząca Koła - Anna Hołowko oraz sekretarz Koła - mgr Jagoda

\section{Działalność Studencko-Doktoranckiego Koła Naukowego "ePRINT" w roku akademickim 2014/2015}

DOI: http://dx.doi.org/10.12775/TSB.2015.031

Rycharska.W wyniku rezygnacji Anny Hołowko z funkcji v-ce przewodniczącej (listopad 2014 r.), powstał wakat, który pozostał nieobsadzony do końca roku akademickiego. Opiekunem Koła została dr Małgorzata Kowalska, która wcześniej okazywała członkom KNSI niezbędne wsparcie. Na potrzeby popularyzacji działań SDKN ePRINT powstała nowa strona internetowa (http://sdkn.strikingly.com/), gdzie umieszczono sylwetki pozostałych członków organizacji.

W bieżącym roku członkowie Koła uczestniczyli w czterech konferencji naukowych. 23-24 października wsparli organizacyjnie IV Ogólnopolską Konferencję Naukową „Niewygodne dla władzy. Ograniczenie wolności słowa na ziemiach polskich od wieku XIX do czasów współczesnych" koordynowaną przez IINiB UMK. Wraz z Kołem Naukowym Bibliotekoznawców Uniwersytetu Kazimierza Wielkiego w Bydgoszczy zorganizowali Lokalną Konferencję 
Naukową „Przegląd badań licencjackich, magisterskich i innych inspiracji studenckich", która odbyła się w Bydgoszczy 25 lutego 2015 r. Była to już trzecia lokalna sesja, która przede wszystkim podtrzymywać ma współpracę pomiędzy kołami, a zarazem ośrodkami bibliotekoznawczymi z Bydgoszczy i Torunia. 20 marca miało miejsce największe przedsięwzięcie SDKN ePRINT - I Ogólnopolska Studencko-Doktorancka Konferencja Naukowa „Człowiek - Nauka. Technologia. Informacja”, która przyciągnęła do Torunia 28 referentów z ośmiu ośrodków naukowych z różnych rejonów Polski. Konferencja miała wysoki poziom dzięki ambitnym referatom i doskonale przygotowanym referentom, dyrekcji IINiB UMK w osobie dr hab. Ewy Głowackiej, prof. UMK, która otworzyła konferencję i pracownikom Instytutu (dr hab. Małgorzata Fedorowicz-Kruszewska, dr Wanda A. Ciszewska, dr Małgorzata Kowalska), którzy poprowadzili sesje i moderowali żywe dyskusje słuchaczy i prelegentów. Trwają starania, by do końca 2015 r. ukazała się monografia, stanowiąca pokłosie tej konferencji. Członkowie Koła wsparli także organizacyjnie II Ogólnopolską Konferencję Naukową „Homo Communicativus II. Przestrzeń informacyjna współczesnej nauki", która odbyła się 25-26 czerwca 2015 r. Poza pomocą techniczno-organizacyjną studenci i doktoranci z SDKN ePRINT przetłumaczyli postery na to- warzysząca sesji naukowej wystawę „Places\&Spaces. Mapowanie nauki”.

W związku z połączeniem kół, SDKN ePRINT stało się wydawcą czasopisma „Między Regałami”, zapoczątkowanego przez Prasoznawcze Koło Naukowe. W roku akademickim 2014/2015 ukazały się trzy kolejne numery periodyku, które w odświeżonej szacie edytorskiej, ze zmianami w obrębie struktury czasopisma oraz składzie redakcji trafiły do czytelników zarówno w wersji drukowanej, jak i online. W skład redakcji weszli: opiekunowie merytoryczni - dr Dorota Degen i dr Małgorzata Kowalska, redaktor naczelny - Marcin Karwowski oraz rada redakcyjna - Marcin Karwowski, Piotr Rudera, Jagoda Rycharska. Poza artykułami popularnonaukowymi w „Między Regałami” na stałe zagościły działy: „Biblioteka”, na łamach którego opisywane są placówki biblioteczne różnego typu oraz „Recenzje”, gdzie umieszczane są opisy ciekawych książek, filmów i stron WWW.

W mijającym roku akademickim członkowie Koła aktywnie uczestniczyli w 26 konferencjach i sympozjach naukowych oraz popularnonaukowych, z czego 24 odbywały się w randze imprez ogólnokrajowych bądź międzynarodowych z zakresu informatologii, bibliotekoznawstwa, prasoznawstwa, pedagogiki, psychologii, coachingu i innych. W sumie wygłosili 30 referatów (Marcin Karwowski - 16, Jagoda Ry- 
charska - 3, Magdalena Ostrowska - 3, Weronika Korga - 3, Piotr Rudera - 2, Agata Olkowska - 2, Beata Płuciniczak-Motowidło - 1, Wojciech Leszczyński - 1). Poniżej zamieszczono wykaz konferencji oraz wygłoszonych w ich ramach referatów:

1. Ogólnopolska Konferencja Naukowa „Media. Codzienność. Edukacja” - Bydgoszcz, 30 września 2015 r.; Marcin Karwowski z referatem „Wizerunek szkół w mediach społecznościowych”.

2. Ogólnopolska Konferencja Naukowa „Nowe oblicza przestrzeni informacyjnej w dobie Web 2.0” Ostromecko, 8-9 września 2015 r.; Marcin Karwowski z referatem „Analiza bibliologów jako kanałów komunikacji naukowej”.

3. IV Ogólnopolska Konferencja Naukowa „Niewygodne dla władzy. Ograniczenie wolności słowa na ziemiach polskich od wieku XIX do czasów współczesnych" - Toruń, 23-24 października 2015 r.; Piotr Rudera z referatem „Kontrola słowa w czasopismach satyrycznych Pomorza w dwudziestoleciu międzywojennym".

4. I Pomorska Konferencja Pedagogów i Bibliotekoznawców „(Po) waga książki w kulturze i edukacji”- Gdańsk, 7 listopada 2015 r.; Marcin Karwowski z referatem „Oferta bibliotek pedagogicznych w sferze kultury i edukacji”.
5. XI Ogólnopolska Konferencja Studenckich Kół Naukowych „Zarządzanie informacją - przedmiot badań i narzędzie usprawnień praktycznych" - Kraków, 14 listopada 2015 r; Weronika Korga z referatem „Przekaz podprogowy jako forma manipulowania informacją”, Marcin Karwowski z referatem „Student o INiBie w Internecie”.

6. II Konferencja Coachingowa „Coaching - efektywny rozwój organizacji" - Kraków, 15-16 listopada 2015 r. (udział bierny).

7. III Ogólnopolska Konferencja Naukowa „Ekologia informacji w espołeczeństwie” - Słupsk, 21 listopada 2015 r.; Marcin Karwowski z referatem „Tajemniczy klient w bibliotece - nowa metoda na ocenę jakości usług".

8. V Ogólnopolska Konferencja Naukowa „Zarządzanie informacją w nauce” - Katowice, 27-28 listopada 2015 r.; Marcin Karwowski $\mathrm{z}$ referatem „Autoinformacja informatologów na stronach domowych pracowników instytutów i katedr informacji naukowej i bibliologii”.

9. Konferencja „CreateYourself Stwórz najlepszą wersję siebie!”Warszawa, 28 listopada 2014 r. (udział bierny).

10. Międzynarodowa Konferencja „Reha for the Blind in Poland” Warszawa, 4-5 grudnia 2015 r. (udział bierny). 
11. Konferencja „Wielokulturowa biblioteka” - Gdańsk, 9 grudnia 2015 r. (udział bierny).

12. Lokalna Konferencja Naukowa „Przegląd badań licencjackich, magisterskich i innych inspiracji studenckich" - Bydgoszcz, 25 lutego 2015 r.; Magdalena Ostrowska z referatem „Przydatne aplikacje dla czytelników: przegląd i charakterystyka”, Jagoda Rycharska z referatem „Różnorodność tematów prac dyplomowych, artykułów oraz projektów studentów kształcących się z zakresu bibliologii, bibliotekoznawstwa i informatologii w Niemczech", Marcin Karwowski z referatem „Kim się zostaje, będąc członkiem - absolwentem koła naukowego. Analiza losów członków - absolwentów kujawsko-pomorskich bibliologicznych kół naukowych".

13. Ogólnopolska Konferencja Naukowa „Tematy modne w humanistyce. 0 zwrotach, teoriach i metodach w naukach humanistycznych XX i XXI wieku" - Toruń, 12-13 marca 2015 r.; Marcin Karwowski z referatem „Otwarte dane - przyszłość humanistyki?”.

14. I Ogólnopolska Studencko-Doktorancka Konferencja Naukowa „Człowiek - Nauka. Technologia. Informacja"- Toruń, 20 marca 2015 r.; Agata Olkowska i Weronika Korga z referatem „Narzędzia
Google w życiu studenta”, Jagoda Rycharska z referatem „Wirtualna przestrzeń edukacyjna i jej zasoby”, Magdalena Ostrowska z referatem Krótka historia i charakterystyka wybranych mediów społecznościowych", Piotr Rudera z referatem „Brand journalism na przykładzie biuletynów firmowych", Marcin Karwowski z referatem „Mglistość polskiej nauki".

15. III Ogólnopolska Konferencja Naukowa Dydaktyki Akademickiej „IDEATORIUM” - Gdańsk, 9-10 kwietnia 2015 r.; Marcin Karwowski z referatem „Gamifikacja sposobem na zajęcia z public relations".

16. Ogólnopolska Konferencja Naukowa „Collquia Aesthetica - Efektowne sposoby prezentowania informacji"- Lublin, 10 kwietnia 2015 r.; Jagoda Rycharska z referatem „Wyszukiwarki i wyszukiwanie wizualne”, Weronika Korga z referatem „Design stron internetowych - jak radzą sobie biblioteki?".

17. Ogólnopolska Konferencja Naukowa „Nauka kontra magia. Różne oblicza fantastyki” - Warszawa, 17 kwietnia 2015 r.; Marcin Karwowski z referatem „Teorie źródeł magii w literaturze polskiej i zagranicznej".

18. VI Ogólnopolska Konferencja Bibliologicznych Kół Naukowych 
„Warsztat informacyjny XXI wieku" - Bydgoszcz, 22 kwietnia 2015 r.; Agata Olkowska z referatem „Programy open source przydatne w bibliotece”, Wojciech Leszczyński z referatem „Sieć semantyczna jako podstawowe założenie Internetu trzeciej generacji (Web 3.0)", Marcin Karwowski z referatem "Warsztat informacyjny infobrokera".

19. Ogólnopolska Interdyscyplinarna Konferencja Naukowa „W rytmie zegara... Interpretacje” - Olsztyn, 24-25 kwietnia 2015 r.; Marcin Karwowski z referatem „Zegar narzędzie do zarządzania czasem".

20. Sympozjum Naukowe „Educational Cha(lle)nge. Nowoczesne metody wspierania edukacji i rozwoju" Gdańsk, 14 maja 2015 r. (udział bierny).

21. IX Bałtycka Konferencja Naukowa Zarządzanie i Organizacja Bibliotek „Zarządzanie zasobami niematerialnymi bibliotek w społeczeństwie wiedzy" - Gdańsk, 14-15 maja 2015 r.; Marcin Karwowski z referatem „Secret client - metoda pomiaru niematerialnych zasobów biblioteki".

22. II Ogólnopolska Konferencja Naukowa „Homo Communicativus. Przestrzeń informacyjna współczesnej nauki" - Toruń, 25-26 czerwca 2015 r.; Magdalena Ostrowska z referatem „Dedykowane serwisy służące udostępnianiu książek naukowych", Marcin Karwowski z referatem „Bibliologia i informatologia - obszary badań i ich finansowanie w ramach wybranych konkursów NCN".

23. Konferencja „Środa z Funduszami dla organizacji pozarządowych na aktywizację społeczną i zawodową" - Gdańsk, 1 lipca 2015 r. (udział bierny).

24. IV Ogólnopolska Konferencja Naukowa „Ekologia informacji jako wyzwanie dla edukacji i bibliotekarstwa XXI wieku" - Słupsk, 11 września 2015 r.; Marcin Karwowski z referatem „Czego na temat ekologii informacji dowie się od bibliotekarzy tajemniczy klient?".

25. Konferencja Naukowa „Neuroekonomia, czyli jak wykorzystać wiedzę o mózgu w biznesie?" - Grudziądz, 28 września 2015 r. (udział bierny).

26. Ogólnopolska Interdyscyplinarna Konferencja Naukowa „Odmienność w kulturze" - Toruń, 28-29 września 2015 r.; Beata Płuciniczak-Motowidło z referatem „Jak oswoić odmienność? Żywa Biblioteka jako metoda przeciwdziałania wykluczeniu społecznemu".

Analogicznie jak w latach ubiegłych również w roku akademickim 2014/2015 studenci i doktoranci zrzeszeni w SDKN ePRINT stale podnosili 